\title{
Migration in South America: an overview of the austral system
}

\author{
R. TERRY CHESSER
}

\section{Summary}

Austral migrants are species that breed in temperate areas of South America and migrate north, towards or into Amazonia, for the southern winter. Migrations among these species are the most extensive of Southern Hemisphere migrations, and the austral system represents a third major migration system, in the sense that the term has been applied to Northern Hemisphere temperatetropical migration. The geography of South America greatly influences the austral system. Lack of east-west geographical barriers and the shape of the continent promote a pattern of partially overlapping breeding and wintering ranges. The suboscine family Tyrannidae, the tyrant-flycatchers, is the largest group of austral migrants, with other major families including Emberizidae, Anatidae, Furnariidae, Accipitridae and Hirundinidae. Tyrant-flycatchers constitute more than one-half of the passerine austral migrants and roughly one-third of total austral migrants, a taxonomic domination seen in no other global migration system. Parallels exist, however, between austral migration and the Nearctic and Palearctic systems. Many of the same families, including Hirundinidae, Anatidae and Charadriidae, exhibit similarly high degrees of migratory behaviour in each system. Passerine migration in the austral system is similar in numbers to that of the Nearctic-Neotropical system, but species migrate shorter distances and breed in more open and scrubby habitats. Possible differences in year-round resource availability between South American and North American temperate forests, in addition to differing availability of these habitats, may contribute to the low numbers of forest-dwelling austral migrants.

Los migrantes australes son especies de aves que nidifican en áreas templadas de América del Sur y migran al norte, hacia Amazonia, durante el invierno austral. Esta migración es la más extensa del hemisferio austral. El sistema austral representa en tamaño el tercer sistema de migración, en el sentido en que dicho término ha sido aplicado a la migración templado-tropical del hemisferio norte. La geografía de América del Sur tiene grandes influencias en el sistema austral. El hecho de que no haya barreras geográficas de este a oeste, de acuerdo con la forma del continente, produce que la migración austral sea en forma parcial antes que fraccionaria. Los suboscines de la familia Tyrannidae (cazamoscas) son el grupo más grande de aves australes que migran. Otras familias que tienen varios representantes incluye Emberizidae, Anatidae, Furnariidae, Accipitridae y Hirundinidae. Los cazamoscas constituyen más de la 
mitad de los passeriformes y aproximadamente un tercio del total de las aves australes que migran, una partición taxonómica que no es observada en otros sistemas migratorios. Existen paralelos entre los sistemas de migración austral, neártico, y paleártico. Estos incluye varias familias en común, las cuales muestran varias similitudes en el comportamiento migratorio de cada sistema. La migración de los passeriformes en el sistema austral es en número similar a la del sistema neártico-neotropical, con la diferencia de que las especies migran distancias más cortas y nidifican en zonas más abiertas y arbustivas. Posibles diferencias en la disponibilidad de recursos a través del año entre los bosques templados de América del Norte y Sur, además de las diferencias en la disponibilidad de ambientes, contribuyen probablemente al bajo número de migrantes australes que viven en el bosque.

\section{Introduction}

Migrations of birds are among the most noticeable of biological phenomena, and the scientific study of migration has a long history. Migrations of birds between arctic and tropical regions, for instance, attracted the attention of scientists as long ago as Aristotle (Dorst 1962), and have been the subject of a number of extensive works, including that of Moreau (1972) on PalearcticAfrican migration, McClure's (1974) study of migration between the Palearctic and South-East Asia, and the volumes of Lincoln (1939), Keast and Morton (1980), Rappole et al. (1983), and others who have researched various aspects of Nearctic-Neotropical migration. These migrations, involving north temperate breeders that move south for the winter, are the most extensive of all avian movements. Regular movements also occur, however, among exclusively tropical species, and among those that breed in the south temperate zone and migrate north during the southern winter.

Research on migration in the Southern Hemisphere or in purely tropical species began in earnest only some 60 years ago with the work of Chapin (1932) in the Belgian Congo. Many others have studied migrants in Africa, and overviews of tropical and southern African migrations include those of Moreau (1966), Benson (1982) and Dowsett (1988). Reviews of Australian migration and intra-Australian migration were presented by Rowley (1974) and Fullagar et al. (1988) respectively. Curiously, however, given that South America has the world's richest avifauna, migration of South American breeding birds has been largely ignored. General discussion of migration among these species, in fact, has more or less been confined to papers by Zimmer (1938), who discussed just a few species, and Sick (1968), who included comments on South American temperate breeders in a discussion of all types of migration in South America.

This is not to suggest that migration in South America has gone unnoticed. That South American birds migrate has been known to ornithologists in southern South America at least since the time of de Azara (1802-1805), whose work on the natural history of Paraguay and north-eastern Argentina afforded observations of changes in the composition and abundance of the avifauna of the area, and was the first of a number of such regional or single-site studies of the South American avifauna. During the late 1800 , many observers and collectors, among them Hudson, Durnford, Holland, Barrows and Gibson, commented in various papers on seasonal changes in the bird life of Argentina. Dabbene 
(1910), Wetmore (1926) and others continued this tradition into the twentieth century, and Belton $(1984,1985)$ and Willis (1988) have recently made important contributions to the study of migration in southern Brazil.

Seasonal changes in avifauna are more pronounced in temperate regions than in tropical areas, owing to higher avian diversity in the tropics and more extreme seasonal shifts in climate in temperate areas. Therefore, migration in temperate South America is relatively conspicuous. Many South American migrants move north in winter to warmer portions of temperate or subtropical South America, and the southern range boundaries of some species merely contract slightly northward during winter. Other south temperate migrants, however, travel enormous distances to winter in the tropics of Amazonia. Realization that certain south temperate migrants winter in the Amazon basin was relatively recent (Zimmer 1931-1955, 1938). Even today, the wintering areas of many of these migrants are poorly known.

In this paper I present an overview of austral migration in South America. Austral migrants are defined here as species that breed in temperate continental South America and migrate north, towards or into Amazonia, during the austral winter. Species are considered migratory if, with year-to-year seasonal regularity, they undergo a north-south shift of the centre of geographic range - that is, the geographic centre of their breeding range differs in latitude from the geographic centre of their wintering range. This includes all disjunct and most partial migrants, except those that undergo only a shift in the centre of gravity of their population with no concurrent shift of range boundaries, but excludes species that undergo only local or elevational migration. The data presented are based mainly on regional and local bird literature. In most cases, only those species that more than one observer or author has considered migratory have been included, although exceptions have been made if the specimen record appears to confirm a single author's observations.

\section{Austral migration: general observations}

South American migration presents unique opportunities for the study of migration systems. Most ecological and evolutionary generalizations concerning migration systems have been derived from sample sizes of one or two: that is, either the Palearctic-African or Nearctic-Neotropical migration system, or both. Keast (1980a), for instance, in discussing the ecology and evolution of the Nearctic-Neotropical migration system, made detailed comparisons with the "parallel" Palearctic-African system. Between them, the Palearctic (including the Palearctic-Asian system) and Nearctic systems cover the great northern land masses, which comprise the majority of the earth's land mass. Continents of the Southern Hemisphere are smaller and do not extend into latitudes as extreme as those of the Northern Hemisphere. Consequently, temperate areas of the Southern Hemisphere are much reduced. South America, in fact, is the only continent whose southern portion experiences a typical temperate regime of warm summers and cold winters. Not surprisingly, only South America has an avifauna in the south that is distinct from that of its tropical areas (Dorst 1962).

Thus, South American austral migration represents a third major migration system, in the sense that the term has been applied to migration between temperate and tropical regions. Although differing in scale from the Palearctic and 


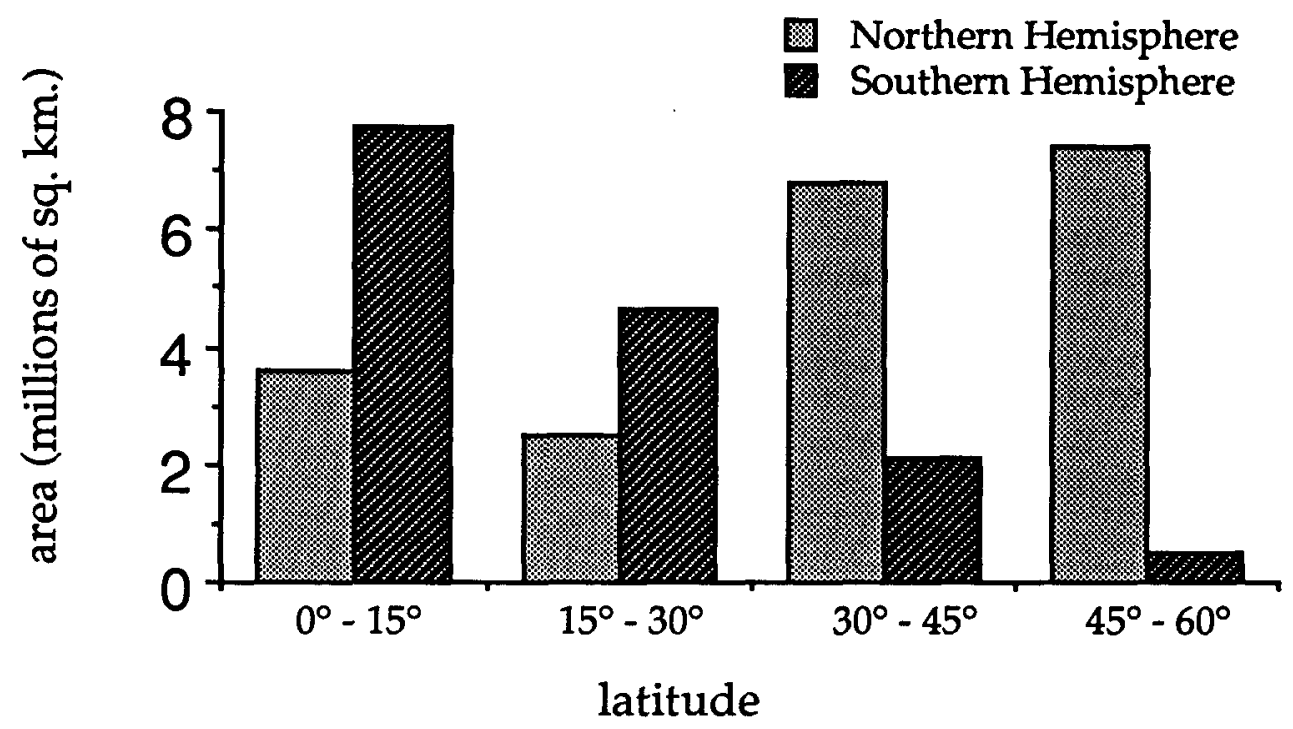

Figure 1. Comparison of land area available to migrants in the Northern and Southern Hemispheres (New World only).

Nearctic systems, it is clearly the most extensive migration system in the Southern Hemisphere and the only one that includes species that migrate distances of several thousand kilometres and breed at latitudes beyond $50^{\circ} \mathrm{S}$. The austral system is, therefore, useful for comparison with the Palearctic and Nearctic systems. In particular, opportunities for comparisons between the Nearctic and austral systems are especially interesting because these migration systems overlap broadly in families, genera and even species.

The geography of the South American continent, in addition to providing opportunities for long-distance migration, shapes other aspects of austral migration. Geographic barriers are thought to affect both migration routes and the pace of migration (Keast 1980a). These are relatively insignificant in the austral system, compared with the Palearctic and Nearctic systems. Major barriers are most prevalent for Palearctic breeders migrating to sub-Saharan Africa, which must potentially cross the Alps, the Mediterranean Sea, and the Sahara or the Middle Eastern deserts. For Palearctic migrants wintering in the Indian subcontinent, the Himalayas present a formidable barrier. Many Nearctic migrants must cross the Gulf of Mexico or Caribbean Sea. In contrast, physical barriers to migration appear to be almost nonexistent in South America: no large bodies of water must be crossed, no massive, continent-wide deserts exist, and the Andes, the major mountain range, run north-south rather than east-west.

The land mass of South America, in contrast to North America or the Palearctic, contains a broad equatorial region, and becomes sharply narrower with increasing southern latitude. Therefore, although breeding grounds of Nearctic and Palearctic migrants are vast and wintering areas are smaller, the situation is reversed for austral migrants. Figure I demonstrates the continuous narrowing of South America with increasing latitude, from nearly eight million $\mathrm{km}^{2}$ between the Equator and $15^{\circ} \mathrm{S}$, to less than a million $\mathrm{km}^{2}$ between $45^{\circ}$ and 
Table 1. Major groups of austral migrants

\begin{tabular}{lccc}
\hline Family & $\begin{array}{c}\text { Migratory species/ } \\
\text { Total breeding species } \\
\text { in South America }\end{array}$ & $\begin{array}{c}\text { Percentage of } \\
\text { family migratory }\end{array}$ & $\begin{array}{c}\text { Percentage of total } \\
\text { austral migrants }\end{array}$ \\
\hline Tyrannidae & $76 / 329$ & 22.8 & 33.2 \\
Emberizinae & $22 / 154$ & 14.2 & 9.6 \\
Anatidae & $17 / 35$ & 48.6 & 7.4 \\
Furnariidae & $\mathbf{1 1 / 2 1 1}$ & 5.2 & 4.8 \\
Accipitridae & $9 / 54$ & 16.7 & 3.9 \\
Hirundinidae & $9 / 18$ & 50.0 & 3.9 \\
Rallidae & $7 / 43$ & 16.3 & 3.1 \\
Laridae & $6 / 17$ & 35.3 & 2.6 \\
Trochilidae & $6 / 233$ & 2.6 & 2.6 \\
Charadriidae & $5 / 13$ & 38.5 & $\mathbf{2 . 2}$ \\
Cuculidae & $5 / 21$ & $\mathbf{2 3 . 8}$ & $\mathbf{2 . 2}$ \\
Caprimulgidae & $5 / 27$ & $\mathbf{1 8 . 5}$ & $\mathbf{2 . 2}$ \\
\hline
\end{tabular}

$60^{\circ} \mathrm{S}$. The pattern in the Northern Hemisphere is essentially the reverse, although there is an indication of the bottleneck that occurs in Central America between $15^{\circ}$ and $30^{\circ} \mathrm{N}$.

As a likely consequence of the lack of geographic barriers and the low ratio of breeding area to wintering area, the breeding and wintering ranges of austral migrant birds are less segregated than are those of Nearctic and Palearctic migrants. Geographic barriers provide natural breaks between breeding and wintering ranges of migrant birds. Furthermore, although birds in general are thought to migrate no further than necessary, competitive effects may result in winter range segregation of similar species, especially when winter quarters are small, with some species perhaps inhabiting more distant wintering grounds than they would in the absence of similar species. Such separation has been proposed for several groups wintering in Central America (e.g. Fitzpatrick 1980a). Most austral migrants, however, have overlapping breeding and winter ranges. This may result from the lack of barriers that would impose range separation, and from the larger areas available to them with each incremental northward movement, easing any potential competitive effects.

\section{Composition and habitat use}

At least 220 species of South American birds are austral migrants (Appendix). The major family represented is the Tyrannidae, or tyrant-flycatchers, with 76 species $(33.2 \%)$, accounting for over half of the passerine migrants (Table 1 ). Such a situation is unique among migration systems: neither the Palearctic nor the Nearctic systems are so dominated by a single family or subfamily, nor are any of the lesser Southern Hemisphere systems. The major group of NearcticNeotropical migrants, for example, the Parulinae, constitutes only $15.1 \%$ (50 of 332 species) of their migration system (Rappole et al. 1983), and inclusion of all migrants from the recently expanded Emberizidae brings this figure only to $27.4 \%$, or 91 of 332 species. Likewise, the Sylviidae or Old World warblers, the most numerous Palearctic-African migrants, make up only $15.5 \%(29 / 187)$ of Palearctic-African migrants (Moreau 1972). That a suboscine family constitutes 
such a large percentage of the austral migration system reflects the numerical importance of suboscines throughout the Neotropics.

Other groups having large numbers of austral migrants include emberizines (22 migrants) and ducks and geese (17). Nine species of the seedeater genus Sporophila are migratory, including most notably $S$. lineola and $S$. caerulescens, as well as three of the ten species of Phrygilus. Three of the five South American representatives of the goose genus Chloephaga are migratory, as are eight species of the large duck genus Anas. The Furnariidae, another suboscine group, also has migratory species; eleven of the distinctive southern furnariids migrate. Other families with large numbers of migrants are the Accipitridae, with 10, and the Hirundinidae, of which nine of the 18 South American breeding species are migratory.

The number of migratory species per family is in part a result of the total number of species in that family. A better indicator of the migratory tendencies of families is the ratio of migratory species to total breeding species. Only 14 of 91 South American families contain more than $20 \%$ migratory species, and eight of these families have fewer than 10 breeding species in South America. Of the six larger families (xo or more breeding species), four - Anatidae, Charadriidae, Laridae, Cuculidae - are non-passerine families, and only two - Hirundinidae and Tyrannidae - are passerines (Table 1). The Tyrannidae, the dominant family by number of species, contains $23 \%$ migratory species. The other families mentioned are more migratory by percentage, and two, the Anatidae and Hirundinidae, include roughly $50 \%$ migratory species.

Migrants are thought to exploit seasonally abundant food resources both on their breeding and wintering grounds (Karr 1976, Keast 1980b), and species from the same family generally have similar diets, general foraging behaviours, and habitats. Therefore, parallelism and convergence might be expected among global migration systems in terms of which families show migratory tendencies, assuming that the families involved are widespread. Those families playing certain ecological roles - aerial insectivores, for example - might be predicted to migrate, whereas others would be expected to be more sedentary. The six migratory families discussed above bear this out. The aerial-feeding Hirundinidae, for instance, are migratory in both the Nearctic and Palearctic migration systems. The Cuculidae, Anatidae, Laridae and Charadriidae are, similarly, migratory in both systems. Likewise, the Tyrannidae, although not present in the Old World, are highly migratory in the Nearctic-Neotropical migration system. Thus, although austral migration is dominated by suboscine species, reflecting its South American locale and history, it is also taxonomically and ecologically similar to other migration systems.

Austral migrants occupy almost all habitats present in temperate South America. The breakdown of breeding habitat for passerines, classified on a continuum from open country to forest (Table 2) shows that the largest single group is the open country avifauna, which occupies grassland, puna and other similar habitats. Most numerous among these are the ground-tyrants Muscisaxicola, breeders along the Andes south to Tierra del Fuego, and a number of southern furnariids. Many tyrants are included as well in the "marsh/aquatic" category, including all four members of the genus Pseudocoloptery $x$, the doraditos. Species in the "open/scrub" or "scrub" categories include many that breed in shrubby 
Table 2. Breeding habitats of austral migrant passerines

\begin{tabular}{lcc}
\hline Habitat type & Number of species & $\begin{array}{c}\text { Percentage of austral } \\
\text { migrant passerines }\end{array}$ \\
\hline Open country & 34 & 24.1 \\
Marsh/aquatic & 13 & 9.2 \\
Open country/scrub & 25 & 17.7 \\
Scrub & 12 & 8.5 \\
Scrub/woodland & 22 & 15.6 \\
Woodland & 15 & 10.6 \\
Woodland/forest & 8 & 5.7 \\
Forest & 12 & 8.5 \\
Total & 141 & 100.0 \\
\hline
\end{tabular}

areas of Patagonia or the scrubbier portions of the Chaco. This category contains greater taxonomic diversity than the others and contains most of the migratory emberizines, both mimids, plus tyrannids, furnariids and members of other groups. Most species in the woodland and forest categories are tyrannids, including several species of Elaenia. Many in these categories migrate the longest distances of any austral migrants (R.T.C. unpublished data).

Wintering habitats of austral migrants, owing in part to the high numbers of partially migratory species, are in many cases similar to their breeding habitats. Several species, however, are known to move in winter into Amazonia, where they experience at least a quite different macrohabitat. At least 24 species are Amazonian migrants, species or subspecies that in general breed mainly outside of Amazonia and winter extensively within Amazonia (Table 3). It is necessary to include both migratory species and subspecies because many of these are species in which one race is migratory whereas others are resident in Amazonia. Most of these are tyrannids, although five families are represented. The centre of winter distribution for a large number of these species seems to be in parts of western Amazonia (R.T.C. unpublished data, T. A. Parker pers. comm.), especially in Peru, northern Bolivia, and western Brazil, although distributions of migrant species are still poorly known in portions of Amazonia.

\section{Tyrannidae, the dominant migrant family}

A closer look at the migratory Tyrannidae (Table 4) reveals that the largest number belong to the subfamily Fluvicolinae, of which 29 of 96 South American breeders are migratory. This assemblage includes not only the highly migratory

Table 3. Passerine austral migrants to Amazonia

\begin{tabular}{lcc}
\hline Family & $\begin{array}{c}\text { Passerine migrants to } \\
\text { Amazonia }\end{array}$ & $\begin{array}{c}\text { Amazonian migrants/ } \\
\text { Total passerine } \\
\text { migrants }\end{array}$ \\
\hline Tyrannidae & 15 & $15 / 76$ \\
Hirundinidae & 5 & $5 / 9$ \\
Turdinae & 1 & $1 / 4$ \\
Vireonidae & 1 & $1 / 1$ \\
Emberizinae & 2 & $2 / 22$ \\
Total & 24 & $24 / 141$ \\
\hline
\end{tabular}


Table 4. Tyrannid genera with more than one migratory species

\begin{tabular}{lcc}
\hline Genus & $\begin{array}{c}\text { Number of migratory } \\
\text { species }\end{array}$ & $\begin{array}{c}\text { Total species in genus } \\
\text { (S.A. only) }\end{array}$ \\
\hline Elaeniinae & & 10 \\
Phyllomyias & 2 & 6 \\
Myiopagis & 2 & 15 \\
Elaenia & 6 & 6 \\
Serpophaga & 3 & 7 \\
Anairetes & 2 & 4 \\
Pseudocolopteryx & 4 & 5 \\
Fluvicolinae & & 2 \\
Xolmis & 2 & 5 \\
Neoxolmis & 2 & 12 \\
Agriornis & 2 & 10 \\
Muscisaxicola & 7 & 10 \\
Knipolegus & 4 & 5 \\
Tyranninae & & 13 \\
Myiarchus & 3 & \\
Tyrannus & 3 & \\
Tityrinae & 2 & \\
Pachyramphus & & \\
\hline
\end{tabular}

genus Muscisaxicola, but a number of related ground-tyrants, including six migrant species from the genera Xolmis, Neoxolmis and Agriornis, which breed throughout Argentina. Also, four species of the genus Knipolegus, the blacktyrants, are migratory. The subfamily Elaeniinae includes 28 migrants out of 168 species; the most migratory genera are the previously mentioned Elaenia and Pseudocolopteryx. The migratory Tyranninae, 16 of 52 species, include members of two genera that contain many migratory species in the NearcticNeotropical system, Myiarchus and Tyrannus. In addition, the Tityrinae contains two migrants from the becard genus Pachyramphus.

Foraging behaviour in the Neotropical Tyrannidae is varied, in contrast to that of the Nearctic migrant tyrannids, and the austral migrant species are no exception (Table 5). The percentage data in Table 5 are presented in two ways: as percentage of migratory tyrannids using each technique relative to the total number of migratory tyrannids, and as percentage of migrant tyrannids using each technique relative to the total number of tyrannids using the technique. The first method allows assessment of the predominant modes of foraging among austral migrants (i.e. what foraging techniques are most often used by austral migrants?), and the second permits determination of the relative migratory propensity of species using a particular foraging technique.

"Perch-gleaning", used by 18 species or $24 \%$ of the migrant tyrannids, is the foraging technique used by more austral migrant tyrannids than any other. It is a predominant mode only in the Elaeniinae, where it is used by such migratory genera as Serpophaga, Anairetes and Pseudocolopteryx. Perch-gleaning is also the main foraging mode of the most migratory of Nearctic groups, the Parulinae, indicating possible convergence between migration systems. Other foraging types used by large numbers of species are "aerial hawking", the predominant mode of 14 migrant species (18\%), "ground-foraging", used by 11 species 
Table 5. Foraging behaviour of austral migrants tyrannids ${ }^{1}$

\begin{tabular}{lcccc}
\hline $\begin{array}{l}\text { Predominant } \\
\text { foraging type }\end{array}$ & $\begin{array}{c}\text { Number of } \\
\text { migrant species }\end{array}$ & $\begin{array}{c}\text { Percentage } \\
\text { of migrants }\end{array}$ & $\begin{array}{c}\text { Total S.A. } \\
\text { tyrannids }\end{array}$ & $\begin{array}{c}\text { Migrants as } \\
\text { percentage of } \\
\text { total } \\
\text { S.A. tyrannids }\end{array}$ \\
\hline Perch-glean & 18 & 24 & 43 & 42 \\
Aerial hawk & 14 & 18 & 33 & 42 \\
Ground & 11 & 14 & 19 & 58 \\
Fruit/hover-glean & 11 & 14 & 54 & 20 \\
Outward hover-glean & 7 & 9 & 31 & 23 \\
Perch to ground & 6 & 8 & 19 & 32 \\
Near ground & 4 & 5 & 17 & 24 \\
Fruit/hawk & 2 & 3 & 6 & 33 \\
Enclosed perch-hawk & 2 & 3 & 15 & 13 \\
Upward strike & 1 & 1 & 92 & 1 \\
\hline
\end{tabular}

${ }^{1}$ Foraging types and data on foraging of tyrannids from Fitzpatrick (1980b). The tityrine genera Pachyramphus and Tityra, not included in Fitzpatrick (1980b), have been added to the "fruit/hoverglean" category. See text for further details.

(14\%), and "fruit/hover-glean", also the predominant mode of 11 species (14\%). Predominant foraging modes of other austral migrant tyrannids include, in order of prevalence, "outward hover-glean" (seven species), "perch to ground" (six), "near ground" (four), "fruit/hawk" (two), "enclosed perchhawk" (two), and "upward strike" (one).

Examination of particular foraging groups reveals that the most migratory is the ground-foraging group, of which 11 of 19 species (58\%) migrate. As might be expected, this is the predominant foraging mode of the ground-tyrants Muscisaxicola, as well as other migratory fluvicoline genera such as Lessonia, Hymenops and Fluvicola. Species employing perch-gleaning and aerial hawking are also highly migratory: $40 \%$ or more of South American tyrannids using these manoeuvres are austral migrants. Tyrants that forage by upward striking are the least migratory group, with only one $(1 \%)$ of 92 species migratory. This large group includes such sedentary, tropical, elaeniine genera as Hemitriccus, Todirostrum, Tolmomyias and Platyrinchus; the only migrant using this technique is the distantly related Myiodynastes maculatus, one of a somewhat atypical upwardstriking genus (Fitzpatrick 1980b).

\section{Comparisons with Nearctic-Neotropical migration}

Rappole et al. (1983) defined Neotropical migrants as migratory species all or part of whose populations breed north of the Tropic of Cancer and winter south of it. Accordingly, they listed 332 species as migratory, of which about half (164) are passerines and half (158) non-passerines. The major groups of NearcticNeotropical migrants (Table 6) are the Parulinae, with 50 species, Tyrannidae (31), Scolopacidae (27), Anatidae (20) and Laridae (20). Other groups relatively well represented are the Emberizinae (17), Trochilidae (13) and Icterinae (13).

The austral migration system can also be considered as a temperate-tropical migration system. In such a case, the inverse of the Nearctic-Neotropical definition would apply: that is, temperate-tropical austral migrants are those migrat- 
Table 6. Major groups of passerine Nearctic-Neotropical migrants (from Rappole et al. 1983)

\begin{tabular}{lcc}
\hline Family & $\begin{array}{c}\text { Number of migratory } \\
\text { species }\end{array}$ & $\begin{array}{c}\text { Percentage of Nearctic- } \\
\text { Neotropical migrants }\end{array}$ \\
\hline Parulinae & 50 & 15.1 \\
Tyrannidae & 30 & 9.0 \\
Scolopacidae & 27 & 8.1 \\
Anatidae & 20 & 6.0 \\
Laridae & 20 & 6.0 \\
Emberizinae & 17 & 5.1 \\
Icterinae & 13 & 3.9 \\
Trochilidae & 13 & 3.9 \\
Ardeidae & 12 & 3.6 \\
Turdinae & 10 & 3.0 \\
Vireonidae & 10 & 3.0 \\
Accipitridae & 10 & 3.0 \\
\hline
\end{tabular}

ory species all or part of whose populations breed south of the Tropic of Capricorn and winter north of it. Considering only passerines, some 122 of 141 austral migrants fit this definition. This is fewer than the 164 passerine NearcticNeotropical migrants, but of the same order of magnitude. That such a large proportion of austral migrant passerines are temperate-tropical migrants also means that few passerines are strictly temperate migrants in South America. Most of these wholly temperate migrants are either furnariids, ground-tyrants or emberizids, including both species of Neoxolmis and the three migratory species of Phrygilus.

Average distance migrated - that is, distance in degrees of latitude from the presumed centre of the breeding range to the presumed centre of the wintering range - was compared for temperate-tropical austral migrant passerines and Nearctic-Neotropical migrant passerines. Distances migrated for NearcticNeotropical migrants were computed from the species maps in Rappole $e t$ al. (1983). Distances migrated for austral-Neotropical migrants were derived from range maps drawn from literature references. Nearctic-Neotropical species migrate an average 22.5 $( \pm 15.7)$ degrees of latitude, whereas austral-tropical species average only $9.2( \pm 8.5)$, a highly significant difference (t-test; $p<0.001$ ).

This result is not surprising, given that little land exists at high latitudes in South America, and that, consequently, breeding ranges of austral migrants tend to occur at lower latitudes than those of Nearctic-Neotropical migrants. There are also differences in relative location of winter ranges. Among passerines, some 42 Nearctic-Neotropical migrants winter in South America. At the extreme are Hirundo rustica, Petrochelidon pyrrhonota and Dolichonyx oryzivorus, which winter in southern temperate latitudes. Although a small number of austral migrant species regularly cross the Equator during migration, the most northerly wintering species of austral migrants scarcely leave South America.

Milder climatic and temperature regimes at higher latitudes in South America, relative to North America, may also promote smaller migration distances in austral migrants. That is, austral migrants may have to travel shorter distances in winter to reach regions of relatively similar resource availability and winter climate. An examination of climatic maps (WMO 1975, 1979) suggests that this may indeed be a factor in distance migrated, although the evidence is better for 


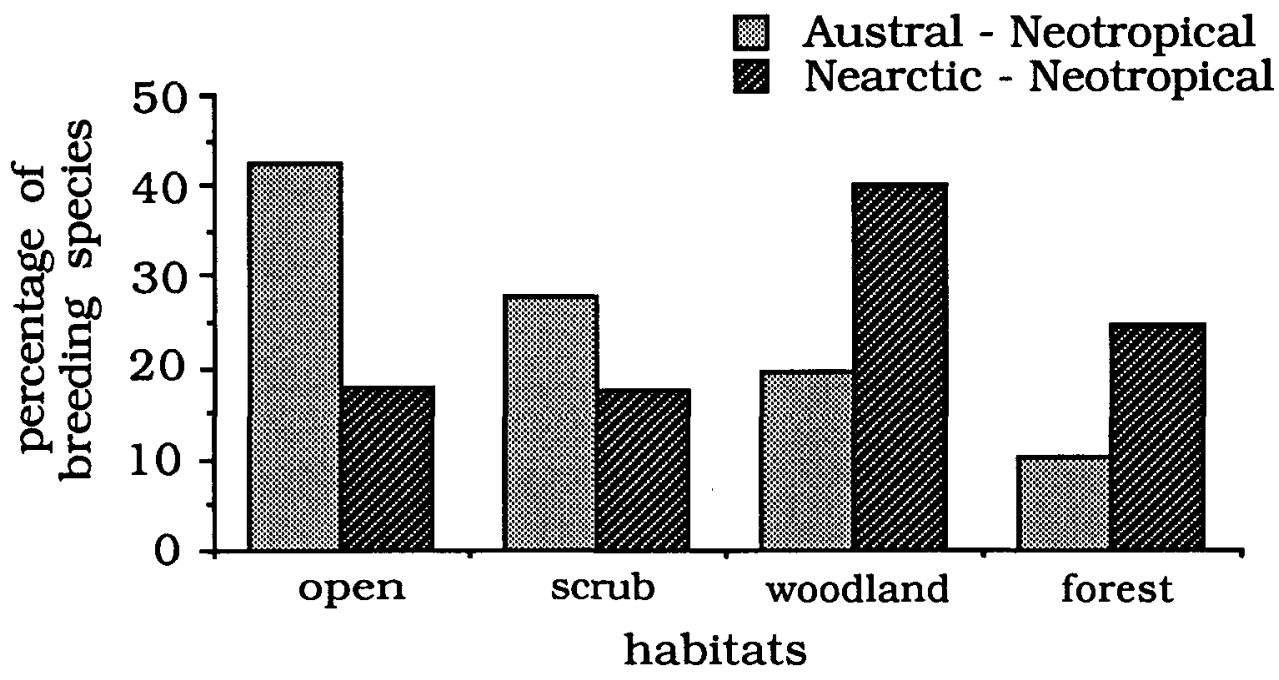

Figure 2. Comparison of austral and Nearctic passerine migrants by breeding habitat. Many habitat categories from Table 2 are combines. Thus, the "open" category here is comprised of the open and marsh/aquatic categories from Table 2, as well as half of the open/scrub species, and so forth.

higher latitudes. Mean midwinter temperature differences between North and South America at $50^{\circ}$ latitude, for instance, average about $15{ }^{\circ} \mathrm{C}$ (roughly $-15^{\circ} \mathrm{C}$ in North America and $0^{\circ} \mathrm{C}$ in South America). However, at the Tropics of Cancer and Capricorn, the dividing lines between temperate and tropical zones, the difference is only about $3^{\circ} \mathrm{C}$ (roughly $13^{\circ} \mathrm{C}$ in North America and $16^{\circ} \mathrm{C}$ in South America).

With respect to breeding habitats, as discussed above, austral migrants tend to occur in open and scrubby areas. Nearctic-Neotropical migrants, in contrast, tend to breed in forest and woodland habitats. About $65 \%$ of the Nearctic tropical migrants breed in forest and woodland, whereas roughly the same percentage of austral temperate-tropical migrants breed in open or scrubby habitats (Figure 2). This in large part reflects differing availability of certain habitats in temperate South America relative to temperate North America. Whereas most of temperate North America is forest and woodland, estimates derived from the vegetational map of Hueck and Siebert (1972) indicate that more than 55\% of temperate South America is open or scrub habitat.

Other factors, however, may also be important in determining the habitats of breeding migrants. Passerine breeding communities in forests of North America generally consist of a majority of Neotropical migrant species. Of passerines breeding at the Hubbard Brook Experimental Forest in New Hampshire, for instance, 14 of 19 species $(73 \%)$ are Nearctic-Neotropical migrants (Holmes et al. 1979). Even in the more climatically buffered forest of the Pacific coast of North America, the percentage of migrant species is fairly high. Data from Breeding Bird Censuses in these forests indicate that roughly $50 \%$ of the breeding species are Nearctic-Neotropical migrants (van Velzen and van Velzen 1983, 1984; censuses 133, 135, 137, and 138 [1983] and 136, 137, 138, and 139 [1984]). 
In contrast, of 16 passerine species recorded by Vuilleumier (1985) as regularly breeding in southern beech forest in Chile and Argentina, only one, Elaenia albiceps, migrates to the tropical zone during the winter. This suggests that year-round resource availability, as determined by climatic or ecological factors, probably differs between temperate North American and temperate South American forests.

Even in the forests of northern Argentina, eastern Paraguay and southern Brazil, where bird diversity is higher, entire categories of migrants are missing, relative to temperate areas in North America. For example, forest-inhabiting, ground-foraging migrants make up a significant portion of the migrant avifauna of temperate North America (e.g. six Turdinae and six Parulinae). However, such migrants are rare or non-existent in the forests of South America (R.T.C. unpublished data).

\section{Conclusions}

The South American austral migration system is the most extensive of those in the Southern Hemisphere. The system is dominated taxonomically by tyrannids, but includes representatives from many families migratory in other regions, including swallows, ducks and shorebirds. Most austral migration involves partially overlapping breeding and wintering ranges, and distances migrated tend to be relatively short, probably owing to the geography of the South American continent. Most austral migrants breed in open country, scrubby or edge habitats, in contrast to Nearctic-Neotropical migrants, most of which breed in woodland or forested areas.

Much is known about austral migration, especially for particular localities, but much remains to be discovered. The overall biogeography of austral migration has yet to be worked out in detail: ranges of many species, and winter ranges in particular, are still only vaguely known or incorrectly given (see, e.g., Marantz and Remsen 1991). Migration routes, especially those of passerines, have generally been ignored. In addition, such patterns as differential migration, leapfrog migration and circle migration, known to occur in other systems, have rarely or never been documented for South American birds. Research on other aspects of austral migration, resource and physiological aspects, for instance, has likewise scarcely begun. As Zimmer (1938) wrote long ago concerning austral migration, it "is an interesting field which is open for study".

\section{Acknowledgements}

I am grateful to the Frank M. Chapman Memorial Fund Committee for support of this project and to $\mathrm{M}$. LeCroy for assistance during my stay at the American Museum of Natural History. I also thank R. A. Paynter for allowing me access to his collection of reprints on the South American avifauna. I thank W. Belton, J. W. Fitzpatrick and J. V. Remsen for many helpful comments on an earlier draft of this manuscript, B. Whitney for providing supplementary data on habitats of austral migrants, D. Stotz for 
stimulating discussions of austral migration, and M. Marín A. and C. Cañás for invaluable help with the Spanish abstract.

Appendix 1. Species list of South American austral migrants. ${ }^{1}$

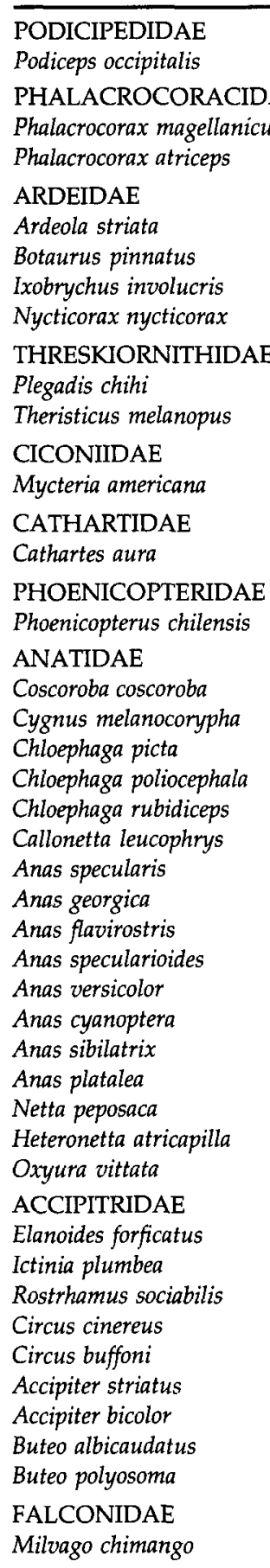

Falco peregrinus

Falco femoralis

RALLIDAE

Rallus sanguinolentus

Coturnicops notata

Gallinula chloropus

Porphyrula martinica

Porphyrula flavirostris

Fulica armillata

Fulica leucoptera

HAEMATOPODIDAE

Haematopus leucopodus

Haematopus ater

CHARADRIIDAE

Vanellus chilensis

Charadrius falklandicus

Charadrius modestus

Oreopholus ruficollis

Pluvianellus socialis

SCOLOPACIDAE

Gallinago gallinago

THINOCORIDAE

Thinocorus orbignyianus

Thinocorus rumicivorus

LARIDAE

Larus belcheri

Larus scoresbii

Larus modestus

Larus maculipennis

Sterna hirundinacea

Sterna trudeaui

PSITTACIDAE

Cyanoliseus patagonus

STRIGIDAE

Glaucidium brasilianum

COLUMBIDAE

Zenaida auriculata

Columbina picui

CUCULIDAE

Coccyzus cinereus

Coccyzus euleri

Coccyzus melacoryphus

Crotophaga major

Tapera naevia

CAPRIMULGIDAE

Lurocalis semitorquatus

Podager nacunda

Hydropsalis brasiliana 
Caprimulgus longirostris

Caprimulgus paroulus

\section{APODIDAE}

Chaetura andrei

Cypseloides fumigatus

TROCHILIDAE

Anthracothorax nigricollis

Patagona gigas

Chlorostilbon aureoventris

Sephanoides sephaniodes

Heliomaster furcifer

Calliphlox amethystina

\section{ALCEDINIDAE \\ Ceryle torquata \\ PICIDAE}

Picoides lignarius

FURNARIIDAE

Geositta cunicularia

Geositta antarctica

Upucerthia dumetaria

Cinclodes fuscus

Cinclodes oustaleti

Cinclodes comechingonus

Phleocryptes melanops

Synallaxis albescens

Synallaxis frontalis

Asthenes pyrrholeuca

Asthenes anthoides

TYRANNIDAE: ELAENIINAE

Phyllomyias burmeisteri

Phyllomyias fasciatus

Camptostoma obsoletum

Phaeomyias murina

Sublegatus modestus

Suiriri suiriri

Myiopagis viridicata

Myiopagis caniceps

Elaenia spectabilis

Elaenia albiceps

Elaenia parvirostris

Elaenia strepera

Elaenia mesoleuca

Elaenia chiriquensis

Serpophaga subcristata

Serpophaga munda

Serpophaga nigricans

Inezia inornata

Stigmatura budytoides

Anairetes parulus

Anairetes flavirostris

Tachuris rubrigastra

Polystictus pectoralis

Pseudocolopteryx dinellianus

Pseudocolopteryx sclateri

Pseudocolopteryx acutipennis
Pseudocolopteryx flaviventris

Euscarthmus meloryphus

TYRANNIDAE: FLUVICOLINAE

Myiophobus fasciatus

Hirundinea ferruginea

Contopus cinereus

Lathrotriccus euleri

Pyrocephalus rubinus

Colorhamphus parvirostris

Xolmis pyrope

Xolmis coronata

Neoxolmis rubetra

Neoxolmis rufiventris

Agriornis murina

Agriornis microptera

Muscisaxicola rufivertex

Muscisaxicola capistrata

Muscisaxicola albilora

Muscisaxicola flavinucha

Muscisaxicola cinerea

Muscisaxicola frontalis

Muscisaxicola macloviana

Lessonia rufa

Knipolegus hudsoni

Knipolegus aterrimus

Knipolegus striaticeps

Knipolegus cyanirostris

Hymenops perspicillata

Fluvicola pica

Alectrurus risora

Satrapa icterophrys

Machetornis rixosus

TYRANNIDAE: TYRANNINAE

Attila phoenicurus

Casiornis rufa

Sirystes sibilator

Myiarchus tyrannulus

Myiarchus swainsoni

Myiarchus tuberculifer

Pitangus sulphuratus

Megarynchus pitangua

Myiodynastes maculatus

Legatus leucophaius

Empidonomus varius

Griseotyrannus aurantioatrocristatus

Tyrannus melancholicus

Tyrannus savana

Tyrannus albogularis

Xenopsaris albinucha

TYRANNIDAE: TITYRINAE

Pachyramphus validus

Pachyramphus polychopterus

Tityra cayana

COTINGIDAE

Procnias nudicollis 
Phibalura flavirostris

Phytotoma rutila

HIRUNDINIDAE

Tachycineta leucorrhoa

Tachycineta leucopyga

Tachycineta albiventer

Notiochelidon cyanoleuca

Progne tapera

Progne chalybea

Progne modesta

Alopochelidon fucata

Stelgidopteryx ruficollis

TROGLODYTIDAE

Troglodytes aedon

MOTACILLIDAE

Anthus hellmayri

Anthus correndera

MIMIDAE

Mimus triurus

Mimus patagonicus

TURDIDAE

Platycichla flavipes

Turdus amaurochalinus

Turdus nigriceps

Turdus subularis

VIREONIDAE

Vireo olivaceus

EMBERIZIDAE: PARULINAE

Geothlypis aequinoctialis

EMBERIZIDAE: ICTERINAE

Leistes superciliaris

Sturnella loyca

EMBERIZIDAE: THRAUPINAE

Piranga flava
Thraupis bonariensis

Tangara preciosa

Tersina viridis

EMBERIZIDAE: CARDINALINAE

Cyanoloxia glaucocaerulea

Pheucticus aureoventris

EMBERIZIDAE: EMBERIZINAE

Melanodera xanthogramma

Catamenia analis

Sicalis luteola

Sicalis auriventris

Sicalis olivacens

Sporophila ruficollis

Sporophila palustris

Sporophila lineola

Sporophila caerulescens

Sporophila melanogaster

Sporophila bouvreuil

Sporophila cinnamomea

Sporophila hypoxantha

Sporophila zelichi

Volatinia jacarina

Phrygilus patagonicus

Phrygilus carbonarius

Phrygilus gayi

Diuca diuca

Poospiza torquata

Poospiza ornata

Zonotrichia capensis

EMBERIZIDAE: CARDUELINAE

Carduelis uropygialis

Total Non-passerines 88 species

Total Passerines $14 \mathrm{I}$ species

TOTAL MIGRANTS 229 species

${ }^{1}$ List derived principally from literature sources, supplemented by specimen records. Further research may result in species removed from or added to this list. See text for further details.

\section{References}

de Azara, F. (1802-1805) Apuntamientos para la historia natural de los páxaros del Paraguay y Río de la Plata, 1-3. Madrid: Imprenta de la Viuda de Ibarra.

Belton, W. (1984) Birds of Rio Grande do Sul, Brazil. 1: Rheidae through Furnariidae. Bull. Amer. Mus. Nat. Hist. 178: 369-636.

Belton, W. (1985) Birds of Rio Grande do Sul, Brazil. 2: Formicariidae through Corvidae. Bull. Amer. Mus. Nat. Hist. 180: 1-242.

Benson, C. W. (1982) Migrants in the Afrotropical region south of the Equator. Ostrich 53: 31-49.

Chapin, J. P. (1932) The birds of the Belgian Congo, 1. Bull. Amer. Mus. Nat. Hist. 65: 1-756.

Dabbene, R. (1910) Ornitología argentina. Anal. Mus. Nac. Buenos Aires 11: 1-513.

Dorst, J. (1962) The migrations of birds. Boston: Houghton-Mifflin. 
Dowsett, R. J. (1988) Migration among South African land birds. Proc. Internatn. Orn. Congr. 19: 765-777.

Fitzpatrick, J. W. (1980a) Wintering of North American tyrant flycatchers in the Neotropics. Pp. $67-78$ in A. Keast and E. S. Morton, eds. Migrant birds in the Neotropics. Washington, D.C.: Smithsonian Institution Press.

Fitzpatrick, J. W. (1980b) Foraging behavior of Neotropical tyrant flycatchers. Condor 82: 43-57.

Fullagar, P. J., Lowe, K. W. and Davies, S. J. J. F. (1988) Intracontinental migration of Australian birds. Proc. Internatn. Orn. Congr. 19: 791-801.

Holmes, R. T., Bonney, R. E. and Pacala, S. W. (1979) Guild structure of the Hubbard Brook bird community: a multivariate approach. Ecology 60: 512-520.

Hueck, K. and Siebert, P. (1972) Vegetationskarte von Südamerika. Stuttgart: Gustav Fischer Verlag.

Karr, J. R. (1976) Seasonality, resource availability, and community diversity in tropical bird communities. Amer. Nat. 110: 973-994.

Keast, A. (1980a) Synthesis: ecological basis and evolution of the Nearctic-Neotropical bird migration system. Pp.559-576 in A. Keast and E. S. Morton, eds. Migrant birds in the Neotropics. Washington, D.C.: Smithsonian Institution Press.

Keast, A. (1980b) Migratory Parulidae: what can species co-occurrence in the North reveal about ecological plasticity and wintering patterns? Pp.457-476 in A. Keast and E. S. Morton, eds. Migrant birds in the Neotropics. Washington, D.C.: Smithsonian Institution Press.

Keast, A. and Morton, E., eds. (1980) Migrant birds in the Neotropics. Washington, D.C.: Smithsonian Institution Press.

Lincoln, F. C. (1939) The migration of American birds. New York: Doubleday.

Marantz, C. A. and Remsen, J. V. (1991) Seasonal distribution of the Slaty Elaenia, a little-known austral migrant of South America. J. Field Orn. 62: 162-172.

McClure, H. E. (1974) Migration and survival of the birds of Asia. Bangkok, Thailand: U.S. Army Medical Comp., South-East Asia Treaty Organization Medical Project.

Moreau, R. E. (1966) The bird faunas of Africa and its islands. New York: Academic Press.

Moreau, R. E. (1972) The Palearctic-African bird migration systems. London: Academic Press.

Rappole, J. H., Morton, E. S., Lovejoy, T. E. and Ruos, J. L. (1983) Nearctic avian migrants in the Neotropics. Washington, D.C.: U.S. Department of the Interior, Fish and Wildlife Service.

Rowley, I. (1974) Bird life. New York: Taplinger Publishing Co.

Sick, H. (1968) Vogelwanderungen im kontinental Südamerika. Vogelwarte 24: 217-243. van Velzen, W. T. and van Velzen, A. C., eds. (1983) Forty-sixth Breeding Bird Census. Amer. Birds 37: 49-108.

van Velzen, W. T. and van Velzen, A. C., eds. (1984) Forty-seventh Breeding Bird Census. Amer. Birds 38: 64-138.

Vuilleumier, F. (1985) Forest birds of Patagonia: ecological geography, speciation, endemism, and faunal history. Pp.255-304 in P. A. Buckley, M. S. Foster, E. S. Morton, R. S. Ridgely and F. G. Buckley, eds. Neotropical ornithology. Washington, D.C.: American Ornithologists' Union (Orn. Monogr. 36).

Wetmore, A. (1926) Observations on the birds of Argentina, Paraguay, Uruguay, and Chile. Bull. U.S. Natn. Mus. 133: 1-448.

Willis, E. O. (1988) Land-bird migration in Sao Paulo, south-eastern Brazil. Proc. Internatn. Orn. Congr. 19: 756-764.

WMO (1975) Atlas climático de America del Sur. Geneva: World Meteorological Organization.

WMO (1979) Climatic atlas of North and Central America. Geneva: World Meteorological Organization. 
Zimmer, J. T. (1931-1955) Studies of Peruvian birds, Nos. 1-66. Amer. Mus. Novit. [between numbers 500 and 1723 inclusive].

Zimmer, J. T. (1938) Notes on migrations of South American birds. Auk 55: 405-410.

\section{R. TERRY CHESSER}

Museum of Natural Science and Department of Zoology and Physiology, Louisiana State University, Baton Rouge, LA 70803-3216, U.S.A. 